ACTA AGROBOTANICA

Vol. 62 (2): 155-164

2009

\title{
ANATOMICAL FEATURES OF LEAVES OF SWEET PEPPER (Capsicum annuum L.) FED WITH CALCIUM USING FOLIAR NUTRITION
}

\author{
Elżbieta Weryszko-Chmielewska ${ }^{1}$, Zenia Michałojć ${ }^{2}$
}

\author{
${ }^{1}$ Department of Botany, University of Life Sciences in Lublin, Akademicka 15, 20-950 Lublin, Poland \\ ${ }^{2}$ Department of Soil Cultivation and Fertilization of Horticutural Plants in Lublin, University of Life Sciences, Leszczyńskiego 58 \\ 20-068 Lublin, Poland \\ e-mail: elzbieta.weryszko@up.lublin.pl
}

Received: 18.09.2009

\section{Abstract}

The effect of three foliar-applied Ca-containing preparations on the anatomical features of leaves of sweet pepper (Capsicum annuum L.) was studied. The following preparations were used: $\mathrm{Ca}\left(\mathrm{NO}_{3}\right)_{2}$, Librel $\mathrm{Ca}$ and Wapnowit, applied at the respective concentrations of $0.5 \%, 1 \%, 1 \%$, which corresponded to a content of $2000 \mathrm{mg} \mathrm{Ca} \times \mathrm{dm}^{-3}$. Light and scanning electron microscopy were used in the study. It was demonstrated that in amphistomatic bifacial pepper leaves numerous specialised cells occurred which accumulated calcium oxalate crystals in the form of crystalline sand. Anisocytic stomata were found with a much greater density in the abaxial epidermis. They were characterized by very well-developed outer cuticular ledges. It was found that in the leaves of the plants sprayed with the nutrient supplements with increased $\mathrm{Ca}$ content there was a much smaller number of epidermal cells per $1 \mathrm{~mm}^{2}$ than in the control plants. These cells were distinguished by an increased size. In the case of the application of the nutrient supplements Librel $\mathrm{Ca}$ and Wapnowit, the number of stomata also decreased. However, the application of the calcium supplements resulted in an increase in the value of the stomatal index compared to the control, which is attributable to a significant reduction in the number of epidermal cells not belonging to the stomata. The plants additionally supplied with Ca were marked by a larger number of colenchyma layers and an increased volume of leaf parenchyma cells.

In the case of pepper leaves, the thin cuticle and the outer cell wall are not a major barrier to the Ca-containing preparations applied for spray treatment. Nevertheless, the decrease in the number of stomata may restrict the possibility of Ca uptake by this way, which compensates the increase in surface area of particular epidermal cells that will be the main way of Ca penetration into the internal leaf tissues.

Key words: Capsicum annuum, foliar nutrition, $\mathrm{Ca}$, leaves, anatomy, changes

\section{INTRODUCTION}

Calcium exhibits low mobility in plant organs. It is passively transported along the xylem elements with the transpiration current and is most frequently accumulated in older leaves ( $\mathrm{S} \mathrm{t}$ a r c k, 1998). Excessive amounts of calcium can be fixed with oxalic acid and deposited in the tissues of such leaves ( $\mathrm{S} \mathrm{ta} \mathrm{r} \mathrm{k}$, 1998). An uneven distribution of calcium in lettuce leaves was found by Choi and Lee (2001) using radioactive $\mathrm{Ca}$. The abovementioned authors also confirmed low mobility of this element in leaves.

Calcium is a component of cell walls in plants. It is found in the middle lamella formed from calcium pectinate. It belongs to the substances encrusting cell walls (calcium carbonate). Therefore, the appropriate supply of plants with calcium affects their proper strength and resistance to pathogenic factors ( $\mathrm{S} t \mathrm{ar} \mathrm{c} \mathrm{k}$, 1998).

Calcium deficiency symptoms manifest themselves primarily in younger leaves which curl and undergo necrosis (Ho and A dam s, 1998). A hidden deficiency of calcium, without revealing external symptoms, may reduce plant yields ( $\mathrm{Mulholland}$ et al. 2001; Michałojć and S zewczuk, 2003).

At the time of fruiting of plants, many elements $(\mathrm{K}, \mathrm{N}, \mathrm{P}, \mathrm{Mg}$ ) move from leaves to fruits. In fleshy fruits (apples, tomatoes, pepper), a high content of potassium and a low content of calcium are found (S t a r c k, 1998). Calcium deficiency symptoms include the following: blossom-end rot in tomato and apple fruit as well as bitter pit in apples. The abovementioned physiological diseases result from local calcium deficiency; hence, they are not caused by an absolute absence of this element, but rather by disorders in the transport of $\mathrm{Ca}^{+2}$ regulated by, among others, cytokinins (W a r d , 1973; H o et al. 1999; M e n g e 1, 2002; 
S u z u ki et al. 2000). With in a plant, calcium is transported almost exclusively through the xylem elements (S t a r ck, 1998).

Anatomical changes occurring in the incidence of blossom-end rot of tomato fruit have been studied by Suzuki et al. (2000). No analysis of the tissues of pepper leaves and fruits in which Ca deficiency and symptoms of blossom-end rot of fruit are found has been made hitherto. The aim of the present study was to compare the structure of the epidermis in pepper leaves and to estimate the range of changes occurring in plants in which symptoms of blossom-end rot of fruit were observed and in plants treated with three different $\mathrm{Ca}$-containing preparations.

\section{MATERIALS AND METHODS}

The study on sweet pepper (Capsicum annuum L.), cv. 'Red Knight' $F_{1}$, was conducted in a greenhouse of the Felin Experimental Farm in 2008 and 2009. The growing period from seed sowing to the termination of the experiment in both years of study was about 7 months (27 February -7 October 2009). Plants were grown in cylinders of $10 \mathrm{dm}^{3}$ volume with a density of 4 plants per $\mathrm{m}^{2}$ in garden peat with an initial $\mathrm{pH}$ of 4.6 , which was subsequently limed with $\mathrm{CaCO}_{3}$ to increase the $\mathrm{pH}$ up to 6.5. The experiments were arranged in a completely randomized design in 8 replications. One plant was one replication.

Fertilization in $\mathrm{g} \times$ plant $^{-1}$ was as follows: $\mathrm{N}-10$ in the form of $\mathrm{KNO}_{3}, \mathrm{NH}_{4} \mathrm{NO}_{3} ; \mathrm{P}-6.0$ as $\mathrm{Ca}\left(\mathrm{H}_{2} \mathrm{PO}_{4}\right)_{2}$ $\times \mathrm{H}_{2} \mathrm{O}$ with a $20.2 \%$ content of $\mathrm{P} ; \mathrm{K}-15$ in the form of $\mathrm{KNO}_{3} 37.3 \% \mathrm{~K}, 15.5 \% \mathrm{~N} ; \mathrm{Mg}-7.0$ as $\mathrm{MgSO}_{4} \times \mathrm{H}_{2} \mathrm{O}$ $17.4 \% \mathrm{Mg}$. Micronutrients were applied in the form of EDTA - Fe, $\mathrm{CuSO}_{4} \times 5 \mathrm{H}_{2} \mathrm{O}, \mathrm{ZnSO}_{4} \times 7 \mathrm{H}_{2} \mathrm{O}, \mathrm{MnSO}_{4}$ $\times \mathrm{H}_{2} \mathrm{O}, \mathrm{H}_{3} \mathrm{BO}_{3},\left(\mathrm{NH}_{4}\right)_{6} \mathrm{Mo}_{7} \mathrm{O}_{24} \times 4 \mathrm{H}_{2} \mathrm{O}$ at amounts used for peat growing media. Micronutrients were supplied to the growing medium once before transplanting the plants to their permanent place. Phosphorus was applied in the middle before transplanting the plants and in the sixth week of growing, whereas nitrogen, potassium and magnesium were supplied at $1 / 7$ before the growing period, and the remaining amounts were applied as top dressing at 10-day intervals.

The effect of the following types of calcium supplements on anatomical changes in sweet pepper leaves was investigated: control (spraying with distilled water); $\mathrm{Ca}\left(\mathrm{NO}_{3}\right)_{2} 19 \% \mathrm{Ca}, 15.5 \% \mathrm{~N}$; Librel Ca - with a composition containing 9.5\% of Ca EDTA,; Wapnowit - with a $11.9 \%$ content of $\mathrm{Ca}, 10 \% \mathrm{~N}$, $0.48 \% \mathrm{Mg}, 0.05 \% \mathrm{~B}, 0.02 \% \mathrm{Cu}, 0.02 \% \mathrm{Zn}$.

Calcium feeding was started from the development phase when the fruits reached the size of a walnut in the first cluster. In the case of nutrient feeding performed every 10 days, $0.6 \mathrm{~g}$ of $\mathrm{Ca}$ was supplied to the plant (10 treatments) within the whole period, whereas in the case of nutrition performed every 20 days, it was $0.3 \mathrm{~g}$ of $\mathrm{Ca}$ (5 treatments). The plants which were sprayed with distilled water at appropriate dates were the control treatment. The working concentration of particular preparations was as follows (percentage weight): $\mathrm{Ca}\left(\mathrm{NO}_{3}\right)_{2},-0.5 \%$; Librel $\mathrm{Ca}-1.0 \%$; Wapnowit $-1.0 \%$, which corresponded to a content of 2000 $\mathrm{mg} \mathrm{Ca} \times \mathrm{dm}^{-3}$.

Leaf samples for microscopic analysis were collected during the termination of the experiment. Leaves were sampled from the middle parts of the plants; they were healthy and fully developed. The structure of the central part of the lamella was analysed. Initial anatomical observations and measurements of lamella thickness were made based on semi-permanent sections, cut manually and embedded in glycerol-gelatine.

Observations of the leaf surface were made using scanning electron microscopy (SEM) after fixing the leaf samples in glutaraldehyde and dehydrating in alcohol series and acetone. After critical-point drying in $\mathrm{CO}_{2}$, the sections were coated with gold and analysed using a TESLA BS-300 microscope.

The examination of the leaf tissues was performed using permanent semi-thin sections with a thickness of $1 \mu \mathrm{m}$. The plant material was fixed in $2.5 \%$ glutaraldehyde and $2 \%$ paraformaldehyde in $0.05 \mathrm{M}$ cacodylate buffer for 3 hours. After dehydration in ethanol series, the samples were embedded in Spurr's resin. The specimens were stained with methylene blue with $1 \%$ azur II.

In order to compare changes in the number and size of epidermal cells and stomata, the semi-permanent sections of leaf epidermis were analysed and the stomatal index was calculated:

$$
\mathrm{I}=\frac{\mathrm{S} \cdot 100}{\mathrm{~S}+\mathrm{E}}(\%)
$$

$\mathrm{S}$ - number of stomata per $1 \mathrm{~mm}^{2}$

$\mathrm{E}$ - number of other epidermal cells per $1 \mathrm{~mm}^{2}$

\section{RESULTS}

\section{Functional anatomy of pepper leaves}

The functional needs of pepper leaves are adjusted to moderate light and moisture conditions, which is characteristic of plants with mesomorphic features. In plants from this group, stomata may occur both in the upper (adaxial) and lower (abaxial) epidermis (Fig. 1 $\mathrm{B}, \mathrm{C})$ The location of stomata on both surfaces belongs to the characteristics of amphistomatic leaves.

In terms of tissue arrangement, the pepper leaf represents the bifacial type (Fig. 1 A-C). On the adaxial 
Table 1

Comparison of the number of stomata, epidermal cells and stomatal indices in the lower (abaxial) epidermis of pepper leaves after spraying with Ca-containing formulations.

\begin{tabular}{|c|c|c|c|c|c|c|c|c|}
\hline \multirow[b]{2}{*}{$\begin{array}{l}\text { Formulation } \\
\text { applied }\end{array}$} & \multicolumn{4}{|c|}{ spraying every 10 days } & \multicolumn{4}{|c|}{ spraying every 20 days } \\
\hline & S & $\mathrm{E}$ & $\mathrm{S}+\mathrm{E}$ & $\begin{array}{c}\text { Stomatal } \\
\text { index } \\
\%\end{array}$ & S & $\mathrm{E}$ & $\mathrm{S}+\mathrm{E}$ & $\begin{array}{c}\text { Stomatal } \\
\text { index } \\
\%\end{array}$ \\
\hline Control & 165.9 & 528.3 & 694.2 & 23.9 & 165.9 & 528.3 & 694.2 & 23.9 \\
\hline $\mathrm{Ca}\left(\mathrm{NO}_{3}\right)_{2}$ & 162.4 & 446.8 & 609.2 & 26.7 & 167.6 & 339.9 & 507.5 & 33.0 \\
\hline Librel Ca & 153.7 & 365.3 & 519.0 & 29.6 & 130.6 & 349.7 & 480.3 & 27.2 \\
\hline Wapnowit & 142.8 & 396.5 & 539.3 & 26.5 & 144.5 & 378.6 & 523.1 & 27.6 \\
\hline
\end{tabular}

$\mathrm{S}$ - number of stomata per $1 \mathrm{~mm}^{2}$

$\mathrm{E}$ - number of other epidermal per $1 \mathrm{~mm}^{2}$

Table 2

Comparison of stoma length in the lower (abaxial) epidermis of pepper leaves after spraying with Ca-containing formulations.

\begin{tabular}{lccc}
\hline & \multirow{2}{*}{$\begin{array}{c}\text { Formulation } \\
\text { applied }\end{array}$} & Stoma length $/ \mu \mathrm{m} /$ \\
\cline { 3 - 4 } $\mathrm{Control}$ & & 28.5 & spraying every 20 days \\
\hline $\mathrm{Ca}\left(\mathrm{NO}_{3}\right)_{2}$ & 29.2 & 28.5 \\
\hline Librel Ca & 30.1 & 30.6 \\
\hline Wapnowit & 29.8 & 29.2 \\
\hline
\end{tabular}

part of the lamella, there occurs one, less frequently two layers of palisade parenchyma, whereas in the abaxial part 3-4 layers of spongy parenchyma are found, with a loose arrangement and large intercellular spaces. At the boundary between the palisade and spongy parenchyma, there are found cells containing in their vacuoles numerous calcium oxalate crystals in the form of crystalline sand (Figs 1B, C). Numerous cells with calcium oxalate crystals are also present in the region of the parenchyma of the leaf midrib (Fig. 1A).

\section{Leaf surface micromorphology}

The cells of both the adaxial and abaxial epidermis in pepper leaf exhibit significant folding of the anticlinal walls (Figs 2A, B). But their outer walls are convex. The surface of the outer walls of the epidermal cells is covered by a thin layer of cuticle which shows fine reticulate sculpture (Fig. 2A). Distinct striation of the cuticle is only visible by the stomata and on the veins (Figs 2C, D). Stomata are found in the lower epidermis at a greater density (Fig. 2B) than in the upper epidermis (Fig. 2A). It was found that in the lower epidermis there were at least 3 times more stomata than in the upper epidermis. In the lower epidermis, they are evenly distributed on the whole surface, whereas in the upper epidermis they are concentrated around the leaf veins. In the areas between the veins of the upper surface of the leaf, the stomata are frequently smaller, closed or not fully developed.

The stomata in pepper leaves are most frequently surrounded by 3 epidermal cells, one of which has a smaller size (Figs 4A, C). Based on this, they were classified as anisocytic stomata which are characteristic of the family Solanaceae. The outer cuticular ledges, located on the surface of the guard cells, are much better developed in the case of the stomata occurring in the lower epidermis of pepper leaves than in the upper epidermis (see Fig. 2A and $\mathrm{B})$. The better development of the cuticular ledges determines the formation of a larger outer vestibule of the stomata (Figs 2C; 3A, B), which performs a role in leaf gas exchange and transpiration. 


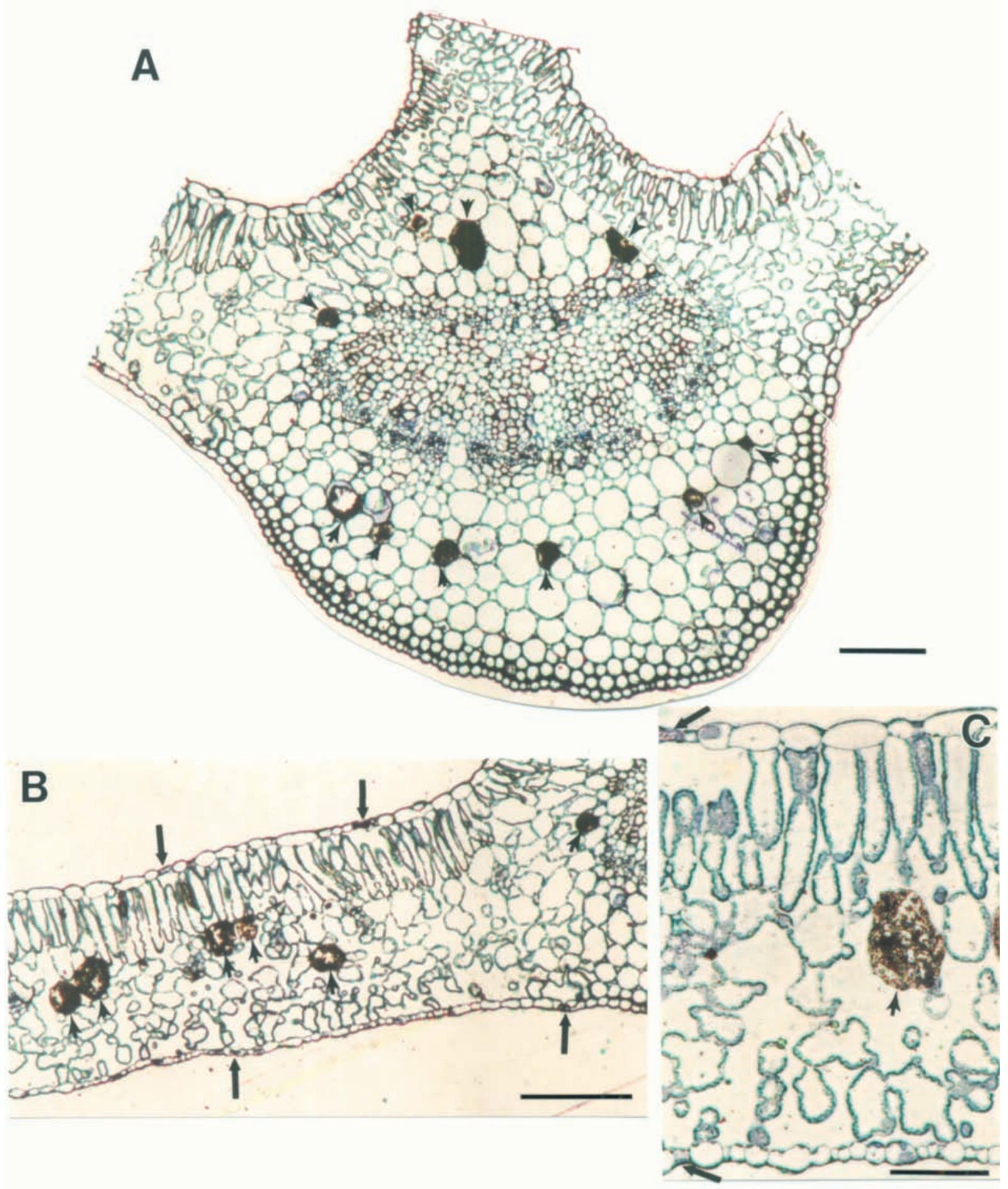

Fig. 1. Cross sections of the leaves of sweet pepper (Capsicum annuum), control plant.

A - Cross section of the midrib. Visible cells with dark content containing calcium oxalate crystals (arrowheads).

B, C - Cross section of the lamina. Visible stomata on both sides of the lamina (arrows) and cells containing calcium oxalate crystals (arrowheads). Scale bars: A, B $-200 \mu \mathrm{m}, \mathrm{C}-100 \mu \mathrm{m}$. 

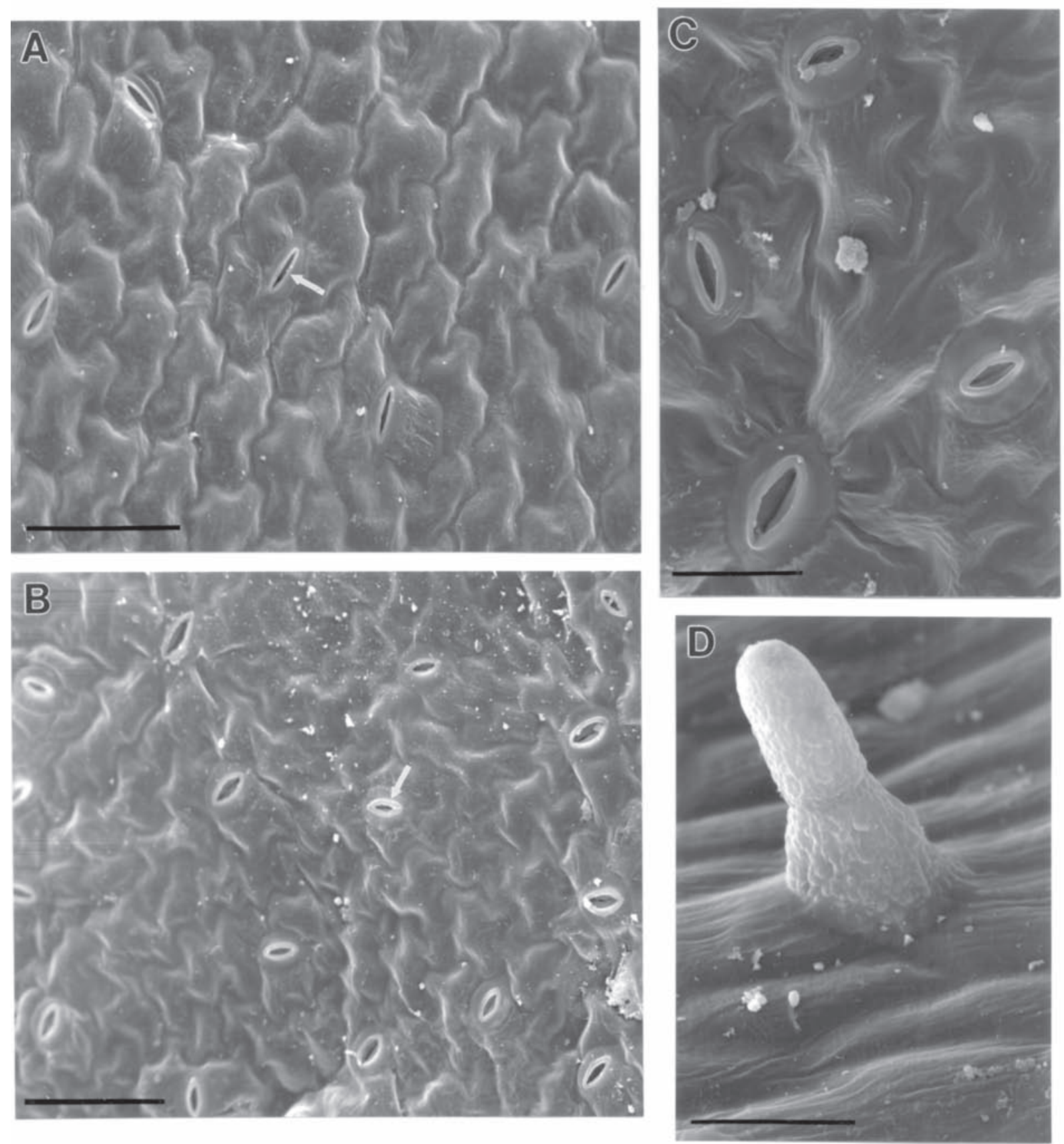

Fig. 2. Surface of epidermal cells of sweet pepper (Capsicum annum) (SEM), control plant.

A - Portion of the surface of the upper (adaxial) epidermis of the control plant with few stomata. Visible convex outer walls.

B - Portion of the surface of the lower (abaxial) epidermis of the control plant with stomata at a significant density. Outer cuticular ledges of the stomata (arrows) are better developed than in the stomata of the upper epidermis.

$\mathrm{C}$ - The surface of the cells of the lower epidermis is covered by a thin cuticle with reticulate or striated sculpture. The stomata have different sizes and their pores are closed.

$\mathrm{D}$ - Portion of the epidermis of the midrib from the lower surface of the leaf with a two-celled non-glandular trichome. Scale bars: A, B $-80 \mu \mathrm{m}, \mathrm{C}-30 \mu \mathrm{m}, \mathrm{D}-50 \mu \mathrm{m}$. 

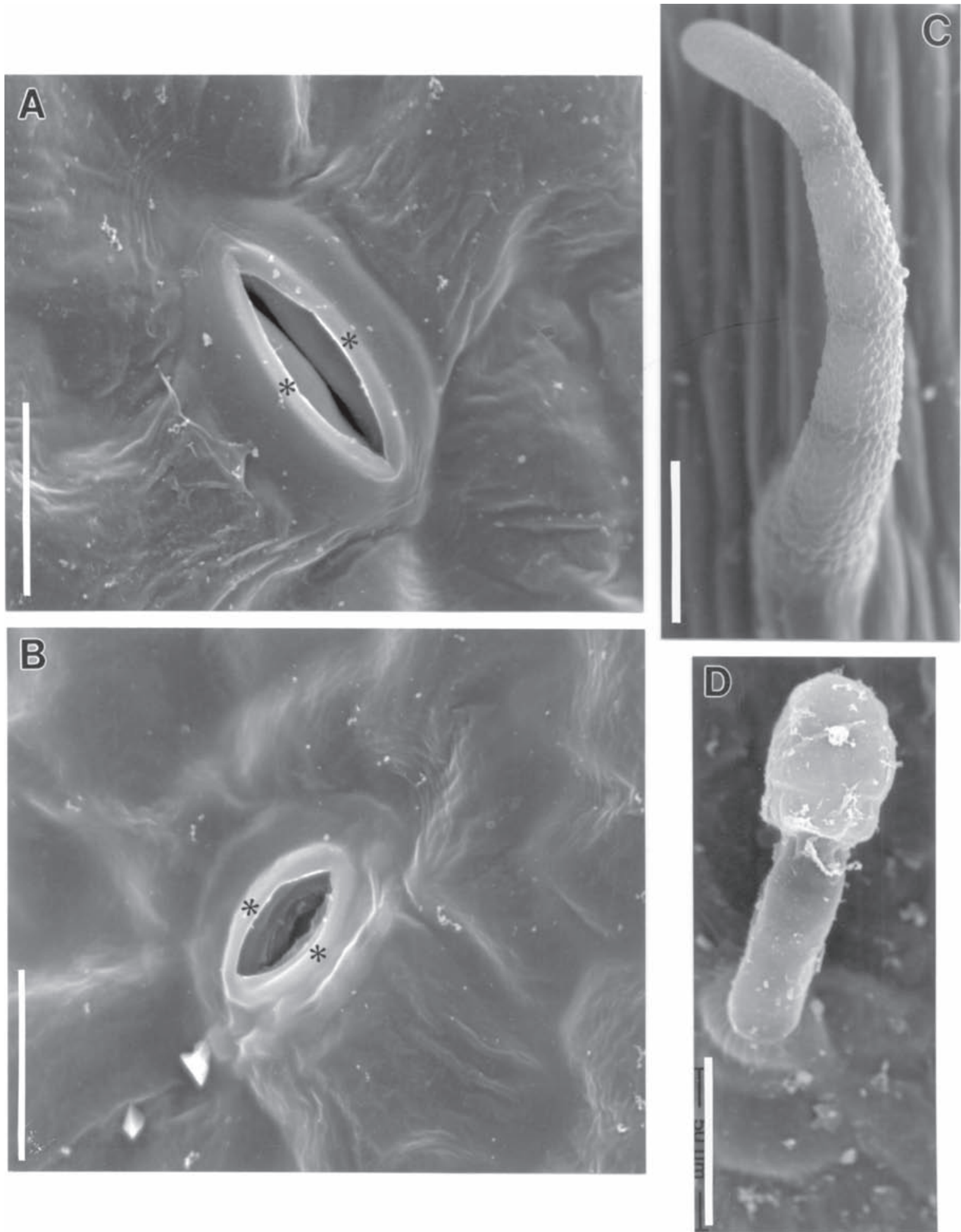

Fig. 3. Portions of the surface of the epidermis of sweet pepper (Capsicum annuum) leaf (SEM), control plant.

A - Closed stoma in the lower epidermis of pepper leaf. The cuticle on the surface of the cells around the stoma exhibits irregular striation.

B - Open stoma in the lower epidermis of pepper leaf. Outer cuticular ledges (asterisks) surround the outer vestibule of the stomata.

$\mathrm{C}$ - Non-glandular trichome in the lower epidermis of pepper leaf on the surface of the midrib, composed of five cells.

D - Glandular trichome from the upper epidermis of pepper leaf with a multi-celled head. Scale bars: A, B - $20 \mu \mathrm{m}, \mathrm{C}-60 \mu \mathrm{m}$, $\mathrm{D}-50 \mu \mathrm{m}$ 

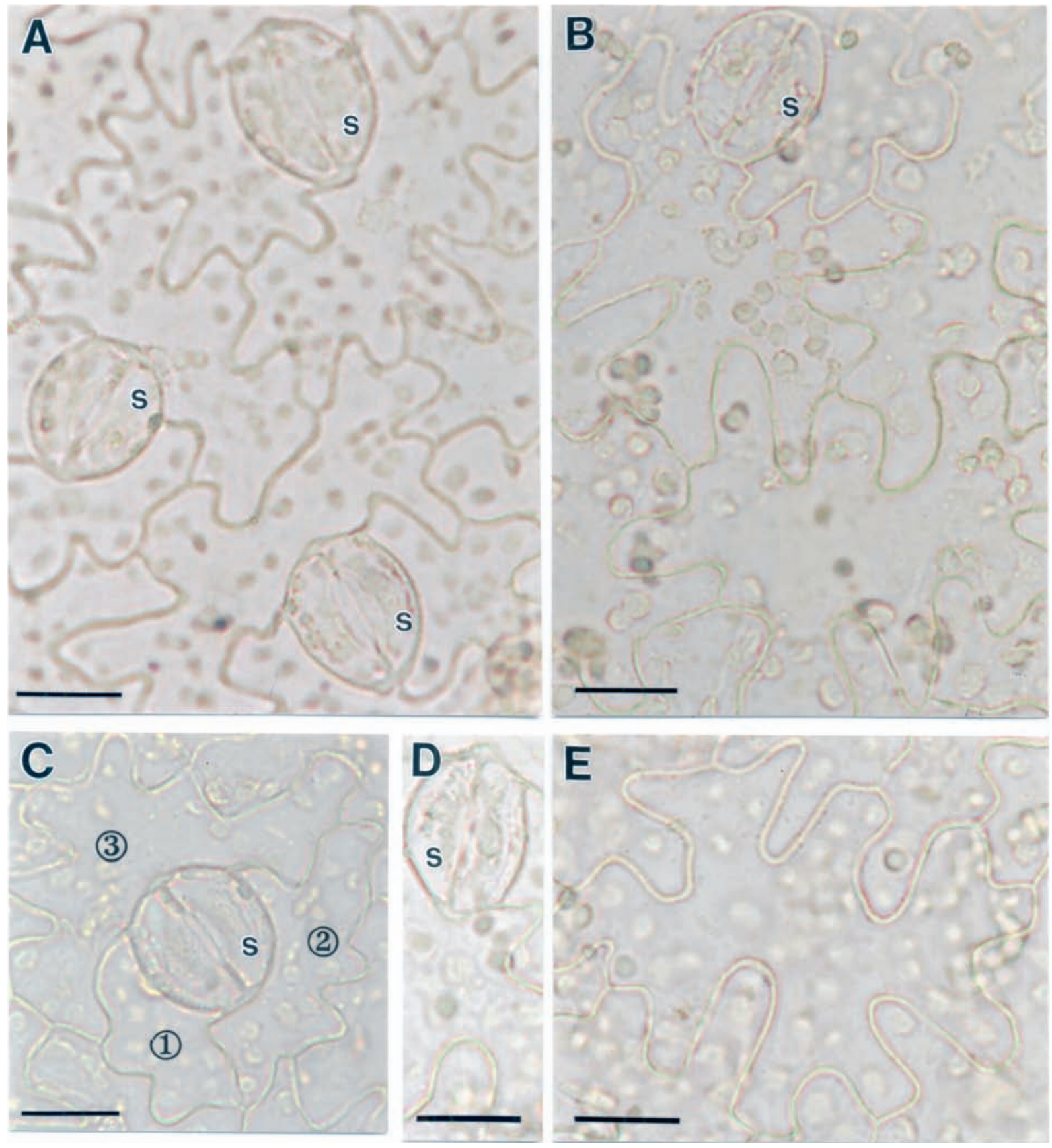

Fig. 4. Cells of the abaxial epidermis of sweet pepper (Capsicum annuum) leaf (LM).

A - Visible numerous stomata (S) and epidermal cells with strongly folded radial walls (control plant).

B - Few stomata and epidermal cells larger than in the control plant after the treatment with the $1 \%$ nutrient supplement Librel Ca.

C - Anisocytic stoma (s) surrounded by three guard cells (1-3) (control plant).

D - Stoma of a plant treated with the $1 \%$ nutrient supplement Librel Ca.

$\mathrm{E}$ - Increased epidermal cell of a plant treated with the $1 \%$ nutrient supplement Librel Ca. Compare the size of cells of the control plant (A, C). Scale bars: A-E - $20 \mu \mathrm{m}$. 

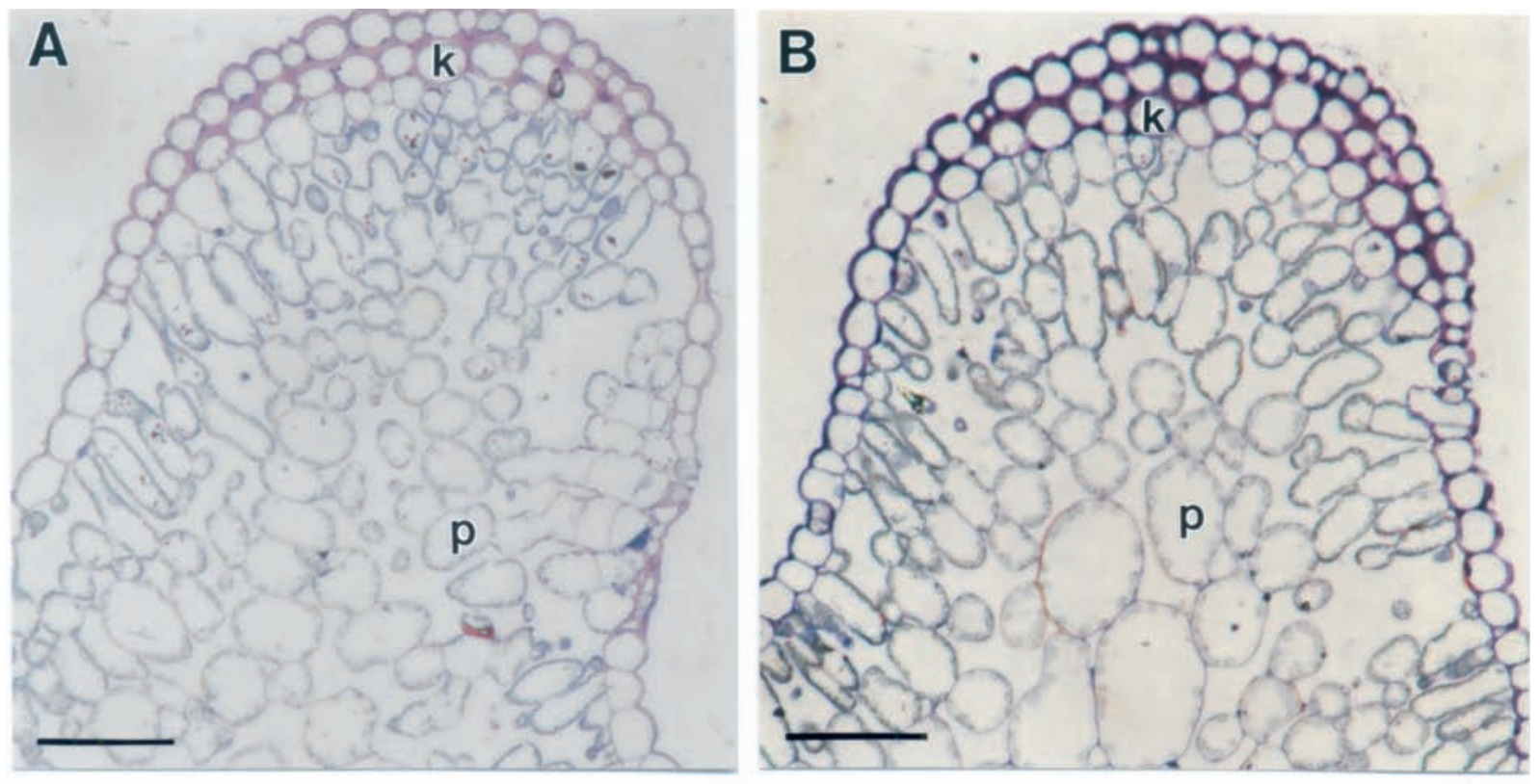

Fig. 5. Part of the cross section of the midrib of sweet pepper (Capsicum annuum) leaf.

A, B - Outgrowth on the upper (adaxial) epidermis of the midrib of sweet pepper (Capsicum annuum) leaf.

A - Control plant. Visible one layer of collenchyma (k) and smaller parenchyma cells (p) than in Fig. B.

B - Plant treated with the $1 \%$ nutrient supplement Librel Ca. Visible two layers of collenchyma (k) and larger parenchyma cells (p) than in the control (A). Scale bars: A, B $-100 \mu \mathrm{m}$.

Different types of trichomes are found on the surface of the veins and in their vicinity in the upper and lower epidermis. Most frequently, these are 2-5-celled living non-glandular trichomes which are rounded at the apex (Figs 2D; 3C). The surface of the cell wall of these trichomes shows numerous granulations. In addition, there occur glandular trichomes composed of a short stalk and a multi-celled head (Fig. 3D).

Due to a number of structural traits of pepper leaves, it can be thought that the penetration of substances used in spraying into the leaf interior occurs with great ease. It is indicated by the following: a thin layer of cuticle, the occurrence of stomata on both sides of the lamella and a large number of stomata in the lower epidermis.

\section{Changes in pepper leaf structure}

A comparison of the stomatal indices of the pepper leaf blades calculated for the abaxial (lower) epidermis shows that there was an increase in the value of these indices in the case of all the applied substances with $\mathrm{Ca}$ content (Tab. 1). It is generally accepted that the stomatal index used in botanical analysis is a quite constant value for a given species. However, our study demonstrates that the treatment of plants with specific substances with $\mathrm{Ca}$ content may result in a change in the value of the stomatal index. We obtained the high- est index (33.0\%) in the plants sprayed with the preparations containing $\mathrm{Ca}\left(\mathrm{NO}_{3}\right)_{2}$, whereas for the control plants it was $23.9 \%$.

As a result of our study, we found that in pepper leaves the number of epidermal cells recorded per $1 \mathrm{~mm}^{2}$ was the highest in the control series. We noted a much smaller number of cells of this tissue in the spraying treatments in which the Ca-containing preparations were applied (Tab. 1). It means that there was an increase in the size of the epidermal cells after the treatment with the preparations with $\mathrm{Ca}$ and that is why their smaller number per unit area was found. The length measurements of the guard cells also show that there was a slight increase in stoma size after the application of the supplements with $\mathrm{Ca}$ (Tab. 2).

The increase in the values of the stomatal indices following spraying with the Ca-containing preparations occurred primarily as a result of a decrease in the number of epidermal cells other than those comprising the stomata, with a slightly reduced number of stomata per unit area (Tab. 1). These changes are associated with the increased size of epidermal cells of the leaf. The study shows that the size of stomata belongs to traits more stable than the size of other epidermal cells, due to a small increase in the length of the guard cells (Tab. 2, Figs 4 A-D) and a much larger increase 
in the size of other epidermal cells (see Figs 4A, C and $4 \mathrm{~B}, \mathrm{E})$ after the treatment of the plants with the nutrient supplements supplying $\mathrm{Ca}$.

Microscopic observations also show that the plants additionally supplied with calcium had better developed layers of subepidermally located collenchyma of the leaf midrib, since this tissue formed at places 2 layers, whereas in the control plants there was only one layer of collenchyma (see Fig. 5A and B). Differences were also found in the range of cell size of the parenchyma occurring in the leaf midrib. Much larger cells occurred in the plants treated with the $0.5 \%$ nutrient supplement Librel Ca than in the control plants (see Fig. $5 \mathrm{~A}$ and $\mathrm{B}$ ).

\section{DISCUSSION}

In the case of pepper, there may be increased demand for $\mathrm{Ca}$ due to the fixation of this element in calcium oxalate crystals in the vacuoles of idioblast cells, occurring in great numbers in leaves of this plant. Crystals in the cells of pepper leaves have the form of crystalline sand. This is a characteristic also encountered in other representatives of the family Solanaceae (K o h l mü n z e r, 1998).

Spraying with the Ca-containing preparations affected the increase in the size of epidermal cells, which resulted in the decrease in the number of cells of this tissue per unit area of leaf. This is the reason why we recorded the increased values of the stomatal indices. It should be stressed that a much larger decline related to the number of epidermal cells which did not form stomata.

In the studied pepper leaves, no differences were observed in the thickness of the outer walls of the epidermal cells after the treatment of the leaves with the calcium supplements. However, the recorded decrease in the number of stomata per unit area of leaf may restrict gas exchange and the uptake of Ca supplied, which occur, among others, thorough stomata (B u rk h ard t and Ei c her t, 2001; M e ng e 1, 2002). According to the latter author, the cuticle-covered surface of all epidermal cells is of much greater importance for the supply of calcium by foliar nutrition. Our observations show that the outer wall of epidermal cells of the pepper leaf is covered by a relatively thin layer of cuticle, which may be a not very difficult barrier to nutrients penetrating into the leaf interior leaf. After the penetration of the cuticle layer, the solutions penetrate into free spaces in the cell wall of the epidermis, which is filled not only with water, but primarily with atmospheric gases (Lohaus et al. 2001). Since only the cell wall spaces filled with water enable the diffusion of the solutions to the inte- rior of leaf tissues, good conditions for foliar nutrition of plants occur only at high air humidity (M e $\mathrm{ng}$ e 1 , 2002), which should be taken into account when spraying is performed.

In accordance with the data of some authors, large amounts of $\mathrm{Ca}$ are located in the walls of plant cells ( $\mathrm{Starck}, 1998$ ). The studies of $\mathrm{Suzuki}$ et al. (2000) show that calcium also occurs in many cell organelles. In the case of its deficit, the dying of cells of tomato and pepper fruit occurs.

\section{CONCLUSIONS}

1. The application of the $\mathrm{Ca}$-containing preparations for spraying of pepper leaves resulted in a decrease in the number of epidermal cells per unit area, which was attributable to a significant increase in the size of these cells. At the same time, in the case of some nutrient supplements there was a reduction in the number of stomata per unit area of leaf, which affected the increase in the stomatal index of pepper leaf.

2. In the leaves subjected to spraying, there was an increase in the number of layers of collenchyma tissue and in the size of parenchyma cells.

\section{Acknowledgments}

This study was supported by a grant from the Polish Ministry of Science and Higher Education, grant: NN 310037933.

\section{REFERENCES}

Burkhardt J., Eichert T., 2001. Stomatal uptake as an important factor in foliar nutrition. In: Plant Nutrition. W.J. Horst et al. (Eds). Kluwer Academic Publisher, Dordrecht, Boston, London.

Choi K. Y., Lee Y. B., 2001. Effect of salinity of nutrient solution on growth, translocation and accumulation of ${ }^{45} \mathrm{Ca}$ in butterhead lettuce. Acta Hort. 548: 575-580.

Ho L. C., Adams P., 1989. Calcium deficiency: a master of inadequate transport to rapidly growing organs. Plants Today 2: 202-207.

Ho L. C., Hand D. J., Rus sell M., 1999. Improvement of tomato fruit quality by calcium nutrition. Acta Hort. 481: 463-468.

Kohl mün zer S., 1998. Farmakognozja. Wydawnictwo Lekarskie PZWL, Warszawa.

Lohaus G., Pennewiess K., Sat tel macher B., Hus sman n L., Muehling K. H., 2001. Is the infiltrationcentrifugation technique appropriate for the isolation of apoplastic fluid? A critical evaluation with different plant species. Physiol. Plant. 111: 457-465.

Menge1 K., 2002. Alternative or Complementary Role of Foliar Supply in Mineral Nutrition. Acta Hort. 594: 33-47. 
Michałojć Z., Szewczu k Cz., 2003. Teoretyczne aspekty dolistnego dokarmiania roślin. / Theoretical aspects of foliar feeding of plants. Acta Agroph. 85: 9-17.

Mulholland B. J., Fussell M., Edmondson J., B a sham J., Mckee J. M. T., 2001. Effect of vpd, K nutrition and root-zone temperature on leaf area development, accumulation of $\mathrm{Ca}$ and $\mathrm{K}$ and yield in tomato. Jour. Hort. Sci. Biotech. 76: 641-647.

St a rck Z., 1998. Gospodarka mineralna roślin. [In:] J. Kopcewicz, S. Lewak, (eds), Fizjologia roślin, Państwowe Wydawnictwo Naukowe, Warszawa (in Polish).

Suzuki K., Takeda H., Egawa Y., 2000. Morphological aspect of blossom - end rot fruits of tomato. Acta Hort. 511: 257-264.

Ward G. M., 1973. Causes of blossom-end rot of tomatoes based on tissue analysis. Can. J. Plant Sci. 53: 169-174.

\section{Cechy anatomiczne liści papryki słodkiej (Capsicum annuum L.) dokarmianej pozakorzeniowo wapniem}

\section{Streszczenie}

Badano wpływ trzech preparatów zawierających $\mathrm{Ca}$ stosowanych drogą dokarmiania dolistnego na cechy anatomiczne liści papryki słodkiej (Capsicum annuum L.). Wykorzystano: $\mathrm{Ca}\left(\mathrm{NO}_{3}\right)_{2}$, Librel Ca oraz Wapnowit stosowane odpowiednio w stężeniach) $5 \%, 1 \%, 1 \%$, co odpowiadało zawartości 2000 $\mathrm{mg} \mathrm{Ca} \mathrm{x} \mathrm{dm}{ }^{-3}$. Do badań wykorzystano mikroskopię świetlną i skaningową elektronową. Wykazano, że w amfistomatycznych, bifacjalnych liściach papryki wystepują liczne wyspecjalizowane komórki gromadzące kryształy szczawianu wapnia w postaci piasku krystalicznego. Anizocytyczne aparaty szparkowe wystepowały w znacznie większym zagęszczeniu w epidermie abaksjalnej. Charakteryzowały się bardzo dobrze rozwiniętymi zewnętrznymi listwami kutykularnymi. Stwierdzono, że w liściach roślin spryskiwanych preparatami ze zwiększoną zawartością Ca występowała znacznie mniejsza liczba komórek epidermy w $1 \mathrm{~mm}^{2}$ niż u roślin kontrolnych. Komórki te odznaczały się zwiększonymi rozmiarami. W przypadku zastosowania preparatów Librel Ca i Wapnowit nastąpiło także zmniejszenie liczby aparatów szparkowych. Natomiast aplikacja preparatów z Ca wpłynęła na zwiększenie wartości indeksu stomatalnego w porównaniu z kontrolą, co wynika ze znacznego zmniejszenia się liczby komórek epidermy nie należących do aparatów szparkowych. Rośliny zaopatrzone dodatkowo w Ca odznaczały się większą liczbą warstw sklerenchymy i powiększoną objętością komórek parenchymy liścia.

W przypadku liści papryki cienka kutykula i zewnętrzna ściana komórkowa nie stanowią dużej bariery dla zastosowanych do oprysku preparatów z Ca. Jednakże zmniejszenie się liczby aparatów szparkowych może ograniczyć możliwości pobierania $\mathrm{Ca}$ tą drogą, co rekompensuje powiększenie powierzchni poszczególnych komórek epidermy, które będą stanowiły główną drogę przenikania $\mathrm{Ca}$ do wewnętrznych tkanek liścia. 